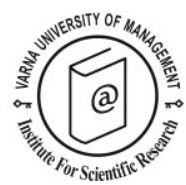

\title{
Analysing Green Meeting Perceptions of Medical Meeting Participants: An Exploratory Research in the Antalya Region of Turkey
}

\author{
Akın Aksu ${ }^{1 *}$, İlker Şahin ${ }^{2}$, Adnan Öztürk ${ }^{3}$ and Selami Gültekin ${ }^{4}$
}

Received: 15/06/2015 Accepted: 21/10/2015

\footnotetext{
${ }^{1}$ Professor, Faculty of Tourism, Akdeniz University, 07058, Dumlupınar Avenue, Antalya, Turkey. Phone:+90 24231022 20, Email:aaksu@akdeniz.edu.tr

${ }^{2}$ Research Assistant, Faculty of Tourism, Akdeniz University, 07058, Dumlupınar Avenue, Antalya, Turkey. Phone:+90 24231028 57, Email: ilkersahin@akdeniz.edu.tr

${ }^{3}$ Research Assistant, Faculty of Tourism, Akdeniz University, 07058, Dumlupınar Avenue, Antalya, Turkey. Phone:+90 24231028 52,Email: adnanozturk@akdeniz. edu.tr

${ }^{4}$ Research Assistant, Faculty of Tourism, Akdeniz University, 07058, Dumlupınar Avenue, Antalya, Turkey. Phone:+90 24231028 54, Email: selamigultekin@akdeniz.edu.tr

* Corresponding author
}

\begin{abstract}
The main purpose of this study is to analyse the effect of green meetings participants' perceptions on behavioural intention related to green practices in the tourism industry. Finding out the factor structure of green meeting perception by means of EFA and confirming the discovered factor structure by using CFA are among the research goals. In this study, quantitative research methods were applied. For this purpose, a total of 275 questionnaires were obtained. The research sample consisted of medical conference participants in Antalya, Turkey in 2014 (health sector representatives including doctors, practitioners, nurses, representatives of medical firms, and academics). According to the results, participants supported all kinds of conservation measures to save food, water, electricity, and paper. They attached large importance to eco-friendly, sustainable applications and positively viewed eco-friendly material usage. In addition, it can be concluded that medical conference participants have higher perceptions regarding the forming of social awareness and increasing the number of eco-friendly green meetings in the world. Also, it can be stated that participants' perceptions of green meetings have an important effect on their behavioural intentions towards eco-friendly practices in the meeting sector. The current study showed that a large number of the participants had the intention of attending green meetings but nearly half of them were not willing to pay more for green meetings. On the other hand, the participants were not sure about paying environmental tax on their travels. The present study pointed out that the participants with green meeting experience had more positive perceptions than those who did not. The originality of this paper stems from being one of the few studies in the context of tourism literature to test the effects of green meeting perception on behavioural intention about green practices and being one of leading studies discovering the factor structure of green meeting perception.
\end{abstract}

(C) 2016 Varna University of Management. All rights reserved 
Keywords: green meetings, sustainability, eco-friendly meeting, behavioural Intention, green applications, sustainable tourism, Antalya, Turkey

Citation: Aksu, A., I. Şahin, A. Öztürk, S. Gültekin (2016) Analysing Green Meeting Perceptions of Medical Meeting Participants: An Exploratory Research in the Antalya Region of Turkey. European Journal of Tourism Research 12, pp. 114-132

\section{Introduction}

The term "green meeting" is adopted when discussing how to minimize the negative environmental effect of the meeting industry. Some sustainable practices in the hospitality and tourism sectors contribute to the reduction of negative environmental influences of the meeting industry, since the meeting industry, to some extent, relies on the tourism and hospitality infrastructure and services (Mykletun et al., 2014:212). A "green" meeting is one that is organized and implemented in such a way that it minimizes negative impacts on the environment and promotes a positive social legacy for the host community. Meetings and events are not stand-alone activities. The average meeting or conference influences a number of other independent, yet interactive industry sectors which, in turn, may produce a direct economic, social and environmental impact at their point of intersection. Meetings thus become stepping stones for sustainability in communities, creating local market demand for reductions in the use of toxic materials, the production of waste and greenhouse gas emissions, and the use of water and energy (Epa, 2015).

Green meetings mean making healthier, safer, less wasteful and less damaging choices for sustainability. These eco-friendly meetings are usually held with the aim of leaving a positive impact on the environment and community. Greening the meetings is a way of doing things that take the present and the future into account by applying sustainable and environmental practices. Eco-friendly practices of green meetings mainly include reducing waste, reusing, recycling, conserving energy and providing water efficiency. Holding a green meeting can help an organization to institute environmental protection measures more broadly, thereby obtaining even greater financial benefits. Along with the positive environmental benefits, greening the meetings can be a good way of saving money for meeting organizers (such as, professional convention organisers - PCOs; hoteliers, stakeholders, meeting planners etc.) as well. However, the green meeting presents an opportunity to educate participants, organizers and suppliers about the benefits of green meetings. Nevertheless, applying green practices has many benefits, both tangible and intangible. Such benefits include greater efficiency and reduced expenses, reduced health risks, stimulation of the local economy, and a healthy, vibrant community. Organizations and businesses can utilize their green actions to build their reputation, to gain positive public image and to differentiate themselves from their competitors in market. Improving their positive reputation and brand value in this way attracts new members and customers and more easily recruits engaged, motivated staff (lowa Recycling Association, 2014; Environmental Affairs Division, 2007).

Like other sectors, the meetings sector faces pressure to be socially responsible as a result of global climate change, changes in customer needs and expectations, and tough competition among rivals. International demand in the meetings sector increases year after year. Given this development, meeting planners are trying to find green, socially responsible practices and venues in order to meet this demand. Today's customers are interested in socially and environmentally responsible companies (Frighetto and Wolf, 2013). According to the Brundtland Report, sustainable tourism meets the needs of present and future generations without compromising their abilities (Mair and Jago, 2010: 78). Today, most countries are concerned with economic growth and improvement of life, resulting in environmental problems, such as water and air pollution (Kim, Kim and Chae, 2014: 37). In 
reality, besides economic growth, it is also important to keep existing and future generations in mind in order to have sustainable development. Being sustainable, in a way, means the greening of everything: greening in technology, greening in different sectors, changes in terms of goods/services, processes, and every type of policy (Mair and Jago, 2010: 78).

Both environmental pollution, which has become an important problem worldwide and depletion of water and energy resources, pose a dangerous risk to future generations and threaten human life. In this regard putting sustainable and eco-friendly applications into practice are primary actions to be taken for minimizing the aforesaid risks and threats. In this context, tourism, in which mass consumption is intensively inherent, can be accepted as one of the industries which these actions are highlighted. Being a significant element of the tourism industry, intrinsically the meetings are among mass consumption areas. This research views green meetings as a new environmental concept in congress and meeting tourism. In line with this objective the most important tourism centre in Turkey and the second biggest congress city after Istanbul, Antalya was chosen as the research area.

One of the primary purposes of this research was to provide exploratory findings that present the effect of green meeting perception on behavioural intentions of attendees. To that end, primarily Exploratory Factor Analysis, Confirmatory Factor Analysis, and Regression Analysis were carried out and the statistical correlation between perception factor and intention to take green practices into account were analysed. Additionally, incomprehensive studies testing perceptions related with ecofriendly meetings are the main reasons that led the researchers to focus on this topic. Finding out the factor structure of medical congress attendee perceptions about green-meetings is also among the main targets of the paper. Another goal of this study is to find out whether the participants are willing to pay more money for attending green meetings. One important goal is to reveal whether the perceptions of the participants change according to their green meeting experience. Also this study aims to create environmental awareness and sustainability among event participants and organizers.

\section{Meeting Industry in Turkey}

In spite of environmental measures in the tourism sector (e.g. green-star certification of eco-friendly touristic hotels and restaurants by Ministry of Culture and Tourism, ongoing EcoLabel known as European Flower certification strategy, financial support programmes of the government such as providing them with a discount in their electric bill), green meetings are an unpopular concept in Turkey. On the other hand insufficient formal records about green meetings held in Turkey and green practices not being very extensive shows that the issue needs further improvement. All these issues led the researchers to design an exploratory study on green meetings. This paper aims to increase the national and international social awareness about ecofriendly green meetings.

When the developments in international meeting tourism are examined, it can be seen that according to ICCA (International Congress and Convention Association) statistics, between 1963 and 1967, there were only 1.795 international meetings in the whole World. Starting from that period the performance of international meetings was over the expectations. For example between 2008-2012 the total number of meetings in the world reached 54.844. From 1963 to 2012 the total number reached 173.432 meetings, which means the number of meetings doubled every 10 years (ICCA,1963-2012: 12). According to 2013 ICCA figures, the top 10 hosting countries included in the meeting sector were; USA, Germany, Spain, France, United Kingdom, Italy, Japan, China, Brazil and Netherlands. In terms of city rankings worldwide the top 5 are; Paris, Madrid, Vienna, Barcelona and Berlin (ICCA 2013: 13,18).

Having deep-rooted history, rich cultural treasures, first-class hotel accommodations, numerous facilities, and easy access to the world's major cities, Turkey is hosting many meetings and conventions, at the junction of Europe and Asia. According to the report of ICCA 2013, of 11.685 international meetings 
held worldwide 221 are hosted by Turkey, placing it 18th in the world rankings. When the figures for 2013 are considered, 2,4 million people in the category of meeting tourism seem to have come from Turkey. These figures exceed 3 million people in 2014. The total revenue of meeting tourism has reached 3 billion American Dollars. Turkey's revenue generated from this area was $\$ 2,5$ billion in 2013. The share of the meeting tourism is 7,7 percent of the 32,3 billion dollars that is the tourism revenue of Turkey (TÜRSAB 2014:8).

According to international meetings statistics (ICCA, 2013), Antalya (which can be evaluated as capital city of Turkey in terms of international tourism movements) is ranked at the $104^{\text {th }}$ place with 23 meetings. However the city of Antalya is the second meeting destination in terms of meeting numbers and technical equipment in Turkey. Being the 4th most visited city in the world, having 300 days of sunshine in a year, and 24 degrees of average air temperature, makes Antalya one of the most beautiful cities in Turkey, having previously been called "heaven on earth", "Pearl of the Mediterranean" and "Turkish Riviera" (Expo2016antalya, 2015). Having taken the importance of transportation in meeting tourism into consideration, Antalya's strong infrastructure of land and air transport solidifies the advantageous position of the city. Acquired technical knowledge (know-how) experience and high quality hospitality services are the main advantages of meeting industry in Antalya. Antalya with an approximately 165 thousand-seat hall capacity doubles Istanbul's 87 thousand-seat hall capacity. Antalya ranks first with $37 \%$ share in the meeting capacity of Turkey. Antalya has made major progress on meeting tourism in the short term. Finally, ICCA's (International Congress and Convention Association,) Plenary Session, in which at least 3,500 professionals driving the meeting industry and convention organizers attended, from 95 countries, was held in Antalya in 2014 (WMDA, 2012).

Turkish Government is striving to extend tourism to 12 months in Turkey. Therefore, potential investments are being supported for the development of meeting tourism. As an example of these investments, Antalya will host
EXPO 2016 which is known as the Universal Botanic Exhibition. During EXPO 2016, approximately 8 million visitors are expected to visit the city. All the aforementioned features were largely effective in carrying out this recent research in Antalya. The city is an ideal survey area in terms of meeting tourism and green meeting for researchers. With reference to Antalya Convention and Visitors Bureau, a total of 211 meetings were carried out in Antalya in 2014 (98 International and 113 national meetings). It is stated that a total of 118.381 participants attended meetings hosted by Antalya. The bureau indicated that 49.211 people had participated in international meetings and 69.170 attendees participated in national meetings. 39 of 98 International meetings held in Antalya in 2014 took place in the medical field, and 85 of 113 national meetings were in the medical field. When meeting tourism data of Turkey for the year 2014 is viewed it reveals that the $58.7 \%$ of the medical meetings were held in Antalya. This shows that medical meetings were held in greater numbers than other types of meetings in Antalya. Considering the high participant rate, the researchers agreed to select the sample from the medical meetings.

\section{Importance of Greening and Green Meetings}

The meeting sector includes all kinds of events, incentives, and exhibitions, including megaevents, such as the Olympic Games, world sporting championships, and World Expos (Boo and Park, 2013: 1129). As there is a growing need for being green, all types of actors in the meetings sector, such as professional convention organisers (PCO), convention centres, governments, meeting hotels, sponsors, exhibitors, and even delegates must be careful. The history of "sustainability" attempts in the meetings sector is young and limited. Therefore, until now, most initiative is taken by individuals and/or organizations (Mykletun, Bartkeviciute and Puchkova, 2014: 213). One example in the sector is the Convention Industry Council (CIC). They identified the green meetings concept and tried to promote green policies by explaining the concept, providing practical guidelines, and obtaining standards (Boo and Park, 2013: 1130; Chen, 2013: 4). 
With the development in the meeting sector, meeting planners are trying to find green, socially responsible practices and venues in order to meet the demand. The supply sides are doing their best. For example, convention centres may obtain green roofs, solar panels, greener transportation options, and so on. In fact, green meeting concepts may decrease costs and have both financial and environmental impacts. According to the Convention Industry Council (2012), at a fiveday event, serving 2200 people breakfast, lunch, breaks, and receptions using china instead of plastic disposables keeps 1890 lbs of plastic from landfills (Lee, Barber and Tyrell, 2013: 223). Both in sustainable tourism and in green meeting applications, the three R's of reduce, reuse, and recycle come to mind. Examples include recycling bins at work and purchasing local products in order to decrease carbon footprint (Strick and Fenich, 2013: 162).

The general profile of meeting participants is that they are mostly rich, financially supported by their institutions or firms at the meeting, well-educated, experienced with travel and accommodations, have high levels of culture, have high expectations, and travel under "time" pressure within a limited programme. They mostly attend meetings to acquire new skills, establish new relationships, meet new people and cultures, and share ideas. Participants can be classified into participating delegates (real conference attendees) and non-participating delegates (accompanying people; Mykletun, Bartkeviciute, and Puchkova, 2014: 215). With the current profile, it is not unusual that participants have constant interest in green applications. According to Cvent (2012), delegates are mainly interested in green policies of meetings such as a central location, use of electronic marketing, use of doublesided printing materials, and choosing buffetstyle menus (Lee, Barber, and Tyrell, 2013: 215).

\section{Green Convention Applications in the Tourism Sector}

Studies of "greening" can be classified into two groups: the macro perspective of researchers (examining cases broadly) and the micro perspective of individual firms (Mair and Jago,
2010: 79). The ideal green meeting minimizes waste and energy before, during, and after the meetings. This is related to the amount of energy used, the amount of materials, and amount of waste created. With 2008 figures, according to the results of a meetings market trend survey, $43 \%$ of association event planners planned a green meeting. Regarding air travel, statistics are as follows: air travel accounts for $2 \%$ of worldwide carbon dioxide (CO2) emissions and $12 \%$ of $\mathrm{CO} 2$ emissions from all transport sources; $80 \%$ of air travel emissions come from passenger flights of more than 900 miles, and transport, in general, accounts for $23 \%$ of global greenhouse gas emissions (Aase, 2009: 1).

In order to have constant and equal guidelines related to greening, the Green Meeting Industry Council, together with the U.S. EPA and the International Standards Organization ASTM International (2014), developed "Green Meeting Standards." These standards are classified into nine major areas (Spatrisano, 2014: 1-2), as follows:

1) Accommodation: Hotels, motels, as well as bed and breakfasts, hostels, or other facilities.

2) Audio-Visual: Including sound, lighting, and staging at meetings.

3) Communications: Event communications, programmes, and promotional materials, including name badges and conference bags, etc.

4) Destinations: Any city or area supporting meetings, including aspects such as municipal recycling, etc.

5) Exhibits: The practices of the general service contractors who set up the shows.

6) Food and Beverage: Related to the restaurants, hotel, or independent caterers serving food and beverages.

7) Meeting Venue: Any facility hosting a meeting.

8) On-Site Office: Practices of an organization related to the meeting while setting up and executing during the event.

9) Transportation: Participant and staff travel.

There are lots of best practices for meeting suppliers suitable to these standards. Convention \& Visitors Bureaus and Destination 
Management companies may obtain supplier information from a database of suppliers of "green" programmes, provide their personnel with information regarding greening efforts, purchase environmentally friendly products, use recyclable plastics, and have maps of local parks available. Hotels and other providers of accommodations can organize energymanagement programmes to decrease electricity usage, start recycling programmes for paper, cardboard, metals, glass, and plastics, and separate organic material for composting. Transportation providers can purchase environmentally friendly products like those with "Energy Star" certification and recycle the used oil, vehicle batteries, and so on. Cruise ships can be careful with energy and water conservation, have a spill-prevention plan, choose locally grown/in-season and organic foods, and supply vegetarian alternatives. Exhibition service providers can print collateral materials double-sided and take away what they do not use during the meeting. Destinations suitable to the main aims of the meeting can be selected, and a check-list of environmental criteria can be used in determining the best venue; cities with better mass-transit systems can be given priority (Convention Industry Council's Green Meetings Report, 2004: 1-14). Another example of integrating sustainable practice can be seen in IMEX America. According to 2012 figures, 94\% of the carpet in the trade show was reused from previous events, 54 metric tons of event waste was recycled, 12 metric tons of organics and service ware were composted, and 1861 kilograms of food and other exposition materials were donated to local charities (Kovaleski, 2013: 32).

Continuous interest in "greening" orients companies to management of green marketing, launching and promoting green goods and services in order to gain a competitive advantage. Today's customers are interested in socially and environmentally responsible companies, providing an opportunity for differentiation. According to the written literature, among the main reasons for companies to manage green marketing are: corporate image, following environmental trends, and taking advantage of green opportunities (Chen and Chang, 2013:64). On the other side, "greening" may have different impacts on consumers. Sometimes, green initiatives result in customer satisfaction, and sometimes not. This is the case, especially, in the tourism sector. Green programmes may attract tourists, or tourists might worry about their comfort being adversely affected by being "green" (Gao and Mattila, 2014:20).

In the tourism sector, there is some written literature regarding "greening"; see, for example, the early work of Kirk (1998), ClaverCartes, Molina-Azerin, Pereira-Moliner, and Lopez-Gamero (2007), Bohdanowicz (2005), and Tzschentke, Kirk, and Lynnich (2004) regarding attitudes of hotel managers towards environmental-management research. Concerning the environmental behaviour of Spanish hoteliers, independent and chain hotel managers in Europe have different environmental attitudes (cited in Rittichainuwat and Mair, 2012: 149). Chafe and Honey (2005), together with the Center on Ecotourism and Sustainable Development and The International Ecotourism Society, conducted a study that reported that at least a third of tourists in the studied sample said that they were willing to pay more to companies that support local communities and conservation (cited in Sox and et al., 2013: 147,148). As Millar and Baloğlu (2011) report, according to the 2008 National Leisure Travel Monitor Survey, $85 \%$ of travellers think of themselves as environmentally conscious (Millar and Baloğlu, 2011: 302).

Most studies have been concerned with accommodation providers in the tourism sector, and environmental subjects seem to have less importance in this sector compared to others. Dimensions of greening identified in the literature include managerial and personal values and attitudes, gaining a competitive advantage, cost savings, social responsibility and improving the image of a firm, complying with regulations, and stakeholder pressure (Mair and Jago, 2010: 79-80).

The recent green meeting studies mainly focused on eco-friendly sustainable practices and green applications that provide beneficial results for the stakeholders in the meeting industry. The common findings of studies in the 
green meeting literature show that the attendees are mostly positive about the ecofriendly practices for sustainability. However, the previous academic studies provided a better understanding of issues of greening. After a comprehensive literature search, the authors found that there have been limited academic studies conducted on green meetings. The findings of previous studies conducted by Sox et al., 2013; Park and Boo, 2010; 2013, Mair and Jago, 2010; Lee et al., 2013; Draper et al., 2011, put forth a great contribution to the current green meeting literature as well. According to the research conducted by Sox et al. (2013), the participants are willing to pay more money for green meetings. Additionally, the study of Draper et.al (2011) put forward important findings related to energy efficiency and eco-friendly material usage in meeting organizations. Mykletun et al. (2014), compared the perceptions of green meetings, their importance, and behaviour intentions by three main stakeholder groups: meeting venue managers, meeting organizers, and meeting delegates. However, Mykletun et al. (2014) revealed that venue managers perceived green meetings more positively compared to meeting delegates.

Another leading study made by Mair and Jago (2009) examined the process of corporate greening, and proposes a general conceptual model of the process. In addition, the paper tested the model in one particular tourism context - that of business events - in order to ascertain the specific nature of the corporate greening process in that context. The paper put forth a general model that may be applied to a number of industry sectors. In their exploratory research, Park and Boo (2010) assessed the current environmental position of the convention industry in America. The study formulated suggestions for future direction in regard to "green" concepts by examining and comparing the perceptions, attitudes, and behavioural intentions of three groups of convention stakeholders: convention attendees, meeting planners, and convention suppliers. They revealed that the perception of environmental impact among the three groups varied depending on which environmentally friendly practices were available to each group. Since there is very limited written research and information investigating "greening" and its relationship to behavioural intentions, the authors believe that this paper will be a valuable addition to the literature.

\section{Methodology}

The research sample consists of medical meetings participants in Antalya in 2014, including health sector representatives such as doctors, practitioners, nurses, representatives of medical firms, and academics. Because of time, place, and financial limitations preventing authors from reaching all meetings participants, when defining the research sample, authors used the convenience sampling method. Questionnaires were delivered to Turkish meeting participants during the coffee breaks and gathered after the last sessions of meetings so as to give the participants enough time for evaluation. The research sample consists of medical congress participants between April 1, 2014 and May 31, 2014 in Antalya city centre and in the Belek region of Antalya. The survey was only conducted on Turkish participants. To obtain the data, a questionnaire containing three parts was given to participants. The first part contained 23 questions, of which 16 were taken from Rittichainuwatt and Mair (2012: 153-155)Rittichainuwatt and Mair also from the work of Draper et al., (2011:164-165)-and Mair and Jago (2010: 86-88). The aim of the initial 23 statements was to find out the perceptions of participants. In the formation of the remaining seven questions the researchers benefited from the study of Sox et al. (2013), literature and experts (a professor and a PCO) views.

The second part of the questionnaire consisted of six questions in total, regarding the demographic aspects of congress participants. Finally, the third and last part of the questionnaire contained nine questions derived from Park and Boo (2010: 102) Lee, Breiter and Choi (2011) and Puchkova (2013: 94). Six of these questions were related to behavioural intention regarding green practices and three of them were about the participant opinions of green meetings. In total, the questionnaire consisted of 38 questions, and a five-point Likert scale was used for evaluation (1-strongly disagree, and 5-strongly agree). 
Aksu, A., I. Şahin, A. Öztürk, S. Gültekin (2016) / European Journal of Tourism Research 12, pp. 114-132 Findings

Table 1. Profile of Respondents

\begin{tabular}{|c|c|c|}
\hline Demographic Aspects & Frequency & Percentage (\%) \\
\hline \multicolumn{3}{|l|}{ Gender } \\
\hline Female & 136 & 49.5 \\
\hline Male & 139 & 50.5 \\
\hline Total & 275 & 100 \\
\hline \multicolumn{3}{|l|}{ Age } \\
\hline $18-34$ & 96 & 34.9 \\
\hline $35-44$ & 115 & 41.8 \\
\hline $45-54$ & 53 & 19.3 \\
\hline 55 and more & 11 & 4.0 \\
\hline Total & 275 & $100 \%$ \\
\hline \multicolumn{3}{|l|}{ Occupation } \\
\hline Public & 191 & 69.5 \\
\hline Private Sector & 65 & 23.6 \\
\hline Self-Employment & 15 & 5.5 \\
\hline Other & 4 & 1.4 \\
\hline Total & 275 & $100 \%$ \\
\hline \multicolumn{3}{|c|}{ Frequency of Attendance at Medical Meetings } \\
\hline First Time & 104 & 37.8 \\
\hline Second Time & 42 & 15.3 \\
\hline Third Time & 44 & 16.0 \\
\hline Fourth Time & 20 & 7.3 \\
\hline Five and More & 65 & 23.6 \\
\hline Total & 275 & $100 \%$ \\
\hline \multicolumn{3}{|c|}{ Green Meeting Experience } \\
\hline No & 241 & 87.6 \\
\hline Yes & 34 & 12.4 \\
\hline Total & 275 & $100 \%$ \\
\hline \multicolumn{3}{|c|}{ Having Information About Green Meeting } \\
\hline No & 221 & 80.4 \\
\hline Yes & 54 & 19.6 \\
\hline Total & 275 & $100 \%$ \\
\hline
\end{tabular}

Table 2. Statements Related to Green Practices in The Meeting Organization

\begin{tabular}{llc}
\hline Variables & Mean & $\begin{array}{c}\text { Standard } \\
\text { deviation }\end{array}$ \\
\hline Reducing waste consumption by eating all food (No leftovers) & 4.73 & 0.57 \\
Increasing number of green meetings in the country and in the world & 4.65 & 0.59 \\
Using recycled notepad-papers from previous meetings & 4.65 & 0.72 \\
Sending leftovers to surrounding farms after meeting & 4.64 & 0.61 \\
Turning off air conditioners in unoccupied meeting rooms & 4.64 & 0.77 \\
Using glasses, forks, and plates during catering, which can be recycled coffee, and tea & 4.63 & 0.81 \\
services & 4.62 & 0.62 \\
Using motion-activated lamp and lighting systems in available areas in meeting & & 0.64 \\
hotels/convention centers & 4.62 & 0.69 \\
Using motion-activated lavatory faucets that save water in meeting hotels/convention & 4.59 & 0.74 \\
centers & 4.58 & 0.85 \\
Raising awareness of congress participants regarding green meetings & 4.57 & 0.86 \\
Taking the support of government and other institutions in order to increase number of & 4.40 & 0.86 \\
green meetings & 4.39 & 0.94 \\
Holding meetings and staying in the same hotel & 4.30 & 0.91 \\
Using new model buses during sightseeing/transfer which have eco-friendly filters on & 4.28 & 1.08 \\
their exhausts & 4.25 & 0.96 \\
Using paperless proceedings (USB drives) & 4.14 & 1.06 \\
Using recycled backdrops, banners from previous meetings & 4.13 & 1.04 \\
Creating e-proceedings and publish on website instead of distributing proceedings & 4.09 & 1.11 \\
Using of ecologically sustainable resources as food containers & 4.08 & 1.05 \\
Serving water in glass instead of plastic bottle & 4.05 & 1.09 \\
Holding evening reception outdoors to avoid using air conditioners & 3.67 & 1.19 \\
Serving local dishes instead of imported food. & 3.64 & 1.31 \\
Using chairs and tables made of eco-friendly materials &
\end{tabular}


Questionnaires were distributed at four medical meetings in the Belek region of Antalya and one medical meeting in Antalya city centre. The Belek region has increasing importance for the medical meeting market Antalya destination. Medical meetings were selected mainly because of their local and global market potential. Between April 1, 2014 and May 31, 2014, 750 questionnaires were distributed before, during, and after sessions of the medical meeting to participants in the 17th National Intensive Care Meeting, 11th National Radiation Oncology Meeting, 36th Turkey Endocrinology and Metabolism Illness Meeting, Third Atrial Fibrillation Meeting, and Seventh Academic Geriatrics Meeting. Of the 750 questionnaires, 325 were collected and 275 questionnaires were accepted as valid by the researchers. The remaining 50 questionnaire forms were dismissed due to missing items. This number (275 questionnaires) was accepted by the authors to perform all of the analyses. For sample size determination the researches benefited from Bartlett, Kotrlik and Higgins (2001). For data analysis SPSS 20.0 was used.

Demographic aspects of medical meetings participants are shown in Table 1. According to Table 1, interestingly, the distribution of gender was very even; 139 of them were men $(50.5 \%)$. Nearly half of the participants $(41.8 \%)$ were between 35 and 44 years of age, whereas onethird belonged to the 18-34 age group. In addition, two-thirds work in the public sector, 23.6 percent work in the private sector, and $5.5 \%$ are self-employed. One-fourth of participants stated that they have attended medical meetings five times or more. Also, there was no significant difference in terms of ratios between first-time $(37.8 \%)$ and secondand fourth-time (38.6\%) attendance of participants. Finally, Table 1 also shows that most of the participants $(87.6 \%)$ had no green meeting experience.
The high means related to eco-friendly measures, showed that the participants have positive perceptions in general for environmental applications. It was recognised that the participants had the highest rate of agreement on the following expressions: Reducing waste consumption by eating all the food (4.73), Increasing number of eco-friendly green meetings in the country and in the world (4.65) Using recycled notepad-papers from previous meetings (4.65), Sending leftovers to surrounding farms after meeting (4.64), Turning off air conditioners in unoccupied meeting rooms (4.64).

In general, the participants appear to have positive perceptions about the prevention of waste and the provision of public awareness, energy water-saving practices. In contrast, the participants appear to be undecided in the following issues: serving more vegetables to reduce consumption of meat and holding small meetings in the garden. Table 2 indicated that the participants have a positive perception in general regarding environmental applications.

When Table 3 is examined, it is observed that the participants are undecided about the expression: The cost of green meetings is very high. Participants believe that green meetings enhance the image and brand value of the sponsor and the event. Furthermore, congress participants believe that green meetings have importance for the future of meeting tourism.

In order to define the structure of the "green meeting" perception scale in the first part of the questionnaire, descriptive factor analysis was applied. With this aim, principle component analysis and Varimax rotation were used. By applying Varimax rotation, 23 statements were put through descriptive-factor analysis. In addition to these, to define the relations among the variables, Bartlett's Test of sphericity (2547.605; p: 0.000) was used. The test results

Table 3. Opinions of the Respondents about Green Meetings

\begin{tabular}{lcc}
\hline Variables & $\begin{array}{c}\text { Mean } \\
\text { Standard } \\
\text { deviation }\end{array}$ \\
\hline The cost of green meetings is very high & 3.06 & 1.22 \\
Green meetings enhance the image and brand value of the sponsor and event. & 3.95 & 1.03 \\
Green meetings have importance for the future of meeting tourism & 4.16 & 0.94 \\
\hline
\end{tabular}


$(p<0.000)$ mean that the statements in the factor analysis have relationships with each other. Also, according to factor analysis results, the KMO (Kaiser Meyer Olkin: 0.896) value shows that the sample was sufficient for evaluation. In terms of statistical evaluation, factors which have eigen-value over 1.00 and factor loads over 0.50 were taken into consideration. During factor analysis, three
statements-"Holding meetings and staying in the same hotel," "Serving local food instead of importing meats/veggies/fruits," and "Using glasses, forks, and plates which can be recycled during catering, coffee, and tea services" were omitted from factor analysis because their factor loads were below 0.50 .

Reliability analysis (Table 4) showed that the

Table 4. Green Meeting Perception Dimensions of Respondents

\begin{tabular}{|c|c|c|c|c|}
\hline \multirow{2}{*}{$\begin{array}{l}\text { Variables } \\
\text { Factor 1: Forming of Social Awareness }\end{array}$} & \multicolumn{4}{|c|}{ Factors } \\
\hline & 1 & 2 & 3 & 4 \\
\hline $\begin{array}{l}\text { Increasing number of eco-friendly green meetings in the country and } \\
\text { in the world }\end{array}$ & 0.676 & & & \\
\hline $\begin{array}{l}\text { Raising awareness of meeting participants regarding green } \\
\text { meetings }\end{array}$ & 0.681 & & & \\
\hline $\begin{array}{l}\text { Taking the support of government and other institutions in order to } \\
\text { increase number of eco-friendly green meetings }\end{array}$ & 0.655 & & & \\
\hline Factor 2: Sustainable Applications & & & & \\
\hline Holding evening reception outdoors to avoid using $A C$ & & 0.542 & & \\
\hline Serving water in glass instead of plastic bottle & & 0.644 & & \\
\hline Using paperless proceedings (USB drives) & & 0.597 & & \\
\hline $\begin{array}{l}\text { Creating e-proceedings and publish on website instead of } \\
\text { distributing proceedings after meeting }\end{array}$ & & 0.701 & & \\
\hline Holding small meetings in the garden & & 0.731 & & \\
\hline Serving more vegetables but reducing meat consumption & & 0.550 & & \\
\hline Sending leftovers to surrounding farms after meetings & & 0.661 & & \\
\hline Factor 3: Eco-friendly Material Usage & & & & \\
\hline Using potted plants/flowers as booth dividers instead of plastic & & & 0.699 & \\
\hline $\begin{array}{l}\text { Using of ecologically sustainable resources (e.g., banana leaves) as } \\
\text { food containers }\end{array}$ & & & 0.710 & \\
\hline Using recycled backdrops, banners from previous meetings & & & 0.501 & \\
\hline $\begin{array}{l}\text { Using new model buses during sightseeing which have eco-friendly } \\
\text { filters on their exhausts }\end{array}$ & & & 0.620 & \\
\hline Using chairs and tables made of eco-friendly materials & & & 0.605 & \\
\hline Factor 4: Conservation Measures & & & & \\
\hline Reducing waste consumption by eating all food (No leftovers) & & & & 0.595 \\
\hline Using recycled notepad-papers from previous meetings & & & & 0.696 \\
\hline Turning off $A C$ in unoccupied meeting rooms & & & & 0.682 \\
\hline $\begin{array}{l}\text { Using motion-activated lavatory faucets that save water in } \\
\text { convention centers/ hotels }\end{array}$ & & & & 0.752 \\
\hline $\begin{array}{l}\text { Using motion-activated lamp and lighting systems in available areas } \\
\text { in convention centers/ hotels congress }\end{array}$ & & & & 0.754 \\
\hline Mean & 4.61 & 4.14 & 4.22 & 4.65 \\
\hline Variance Explanation Rate (\%) & 19.540 & 14.805 & 14.481 & 11.394 \\
\hline Reliability & 0.87 & 0.79 & 0.82 & 0.78 \\
\hline
\end{tabular}

Table 5. Perception Differences of Participants According to Their Green Meeting Experience (MannWhitney U)

\begin{tabular}{lcc}
\hline Variables & Mann-Whitney U-test & p \\
\hline Using of eco-friendly chairs and sitting sets for the meeting & 3227.500 & $0.032^{\star}$ \\
\hline Sending leftovers to surrounding farms after meeting & 3009.000 & $0.002^{\star *}$ \\
\hline Using motion-sensitive lavatory faucets which save water & 3402.000 & $0.045^{\star}$
\end{tabular}


value of Cronbach's Alpha was 0.90. This result shows that in general, the scale was reliable.

In order to define differences between the two groups of independent samples, a nonparametric Mann Whitney $U$ Test (which is useful in preventing outliers from biasing results) was used. Mann Whitney $U$ Test results showed that there was a significant difference in responses between two groups of participants: those who had green meeting experience, and those who did not. These significant differences are shown in Table 5.

According to Mann Whitney $U$ Test results, participants with green meeting experience have more positive perceptions than those who did not on the following statements: "Using ecofriendly chairs and sitting sets for the meetings" (Mann Whitney, $U=3227.5$; $p<0.05$ ), "Sending leftovers to surrounding farms after the meetings" (Mann Whitney, $U=3009 ; p<0.01$ ), and "Using motion-sensitive lavatory faucets which save water" (Mann Whitney, $U=3402$; $\mathrm{p}<0.05)$.

To determine whether there was a significant difference on green meeting perceptions between participants by age group, authors used a Kruskal Wallis $X^{2}$ test; results are shown in Table 6. According to the results, there is a significant difference by age group for the statements "Reducing waste consumption by

Table 6. Perception Differences According to Age (Kruskal-Wallis $X^{2}$ Analysis)

\begin{tabular}{|c|c|c|c|c|c|c|}
\hline Variables & Age Group & $\begin{array}{l}\text { Mean } \\
\text { Range }\end{array}$ & Mean & $x^{2}$ & Df & p \\
\hline $\begin{array}{l}\text { Reducing waste consumption by } \\
\text { eating all food (no leftovers) }\end{array}$ & $\begin{array}{l}18-34 \\
35-44 \\
45-54 \\
55 \text { and more }\end{array}$ & $\begin{array}{l}128.07 \\
138.70 \\
155.92 \\
131.00 \\
\end{array}$ & 4.7345 & 8.496 & 3 & $0.037^{\star}$ \\
\hline $\begin{array}{l}\text { Create e-proceedings and } \\
\text { publishing on website instead of } \\
\text { distributing proceedings after } \\
\text { meetings, }\end{array}$ & $\begin{array}{l}18-34 \\
35-44 \\
45-54 \\
55 \text { and more }\end{array}$ & $\begin{array}{l}127.81 \\
142.47 \\
154.45 \\
100.91\end{array}$ & 4.2800 & 8.466 & 3 & $0.037^{*}$ \\
\hline $\begin{array}{l}\text { Serving more vegetables but } \\
\text { reducing meat consumption }\end{array}$ & $\begin{array}{l}18-34 \\
35-44 \\
45-54 \\
55 \text { and more }\end{array}$ & $\begin{array}{l}120.17 \\
142.50 \\
157.03 \\
154.82\end{array}$ & 3.6727 & 9.406 & 3 & $0.024^{*}$ \\
\hline $\begin{array}{l}\text { Using new model buses which } \\
\text { have eco-friendly filters on their } \\
\text { exhausts }\end{array}$ & $\begin{array}{l}18-34 \\
35-44 \\
45-54 \\
55 \text { and more }\end{array}$ & $\begin{array}{l}123.90 \\
138.38 \\
159.92 \\
151.50\end{array}$ & 4.4073 & 9.487 & 3 & $0.023^{*}$ \\
\hline
\end{tabular}

Note: ${ }^{*} p<0.05$

Table 7. Mann-Whitney U-test Results by Age Group

\begin{tabular}{|c|c|c|c|c|}
\hline Variables & Age group & $\mathbf{N}$ & $\mathbf{U}$ & p \\
\hline \multirow{3}{*}{$\begin{array}{l}\text { Reducing waste consumption by eating } \\
\text { all food (no leftovers) }\end{array}$} & $\begin{array}{l}\text { A: } 18-34 \\
\text { C: } 45-54\end{array}$ & $\begin{array}{l}96 \\
53\end{array}$ & 2036.500 & $0.004^{* *}$ \\
\hline & B: $35-44$ & 115 & & \\
\hline & C: $45-54$ & 53 & 2660.000 & $0.041^{*}$ \\
\hline \multirow{2}{*}{$\begin{array}{l}\text { Create e-proceedings and publishing on } \\
\text { website instead of distributing } \\
\text { proceedings after meetings }\end{array}$} & A: $18-34$ & 96 & \multirow[b]{2}{*}{2063.000} & \multirow[b]{2}{*}{$0.031^{*}$} \\
\hline & C: $45-54$ & 53 & & \\
\hline \multirow{2}{*}{$\begin{array}{l}\text { Serving more vegetables but reducing } \\
\text { meat consumption }\end{array}$} & $\begin{array}{l}\text { A: } 18-34 \\
\text { B: } 35-44\end{array}$ & $\begin{array}{c}96 \\
115\end{array}$ & 4648.000 & $0.041^{*}$ \\
\hline & $\begin{array}{l}\text { A: } 18-34 \\
\text { C: } 45-54\end{array}$ & $\begin{array}{l}96 \\
53\end{array}$ & 1857.500 & $0.005^{* *}$ \\
\hline $\begin{array}{l}\text { Using new model buses which have eco- } \\
\text { friendly filters on their exhausts }\end{array}$ & $\begin{array}{l}\text { A: } 18-34 \\
\text { C: } 45-54\end{array}$ & $\begin{array}{l}96 \\
53\end{array}$ & 1882.500 & $0.003^{* *}$ \\
\hline
\end{tabular}

Note: ${ }^{*} p<0.05,{ }^{* *} p<0.01$ 
eating all food (no leftovers)," "Create eproceedings and publishing on website instead of distributing proceedings after meetings", "Serving more vegetables but reducing meat consumption," and "Using new model buses which have eco-friendly filters on their exhausts." In order to determine which differences by age group were significant, the researchers benefited from the Mann-Whitney U-test (see Table 7).

According to the results, participants belonging to the 45-54 age group had more positive perceptions than other age groups for the statements "Reducing waste consumption by eating all food (no leftovers)", "Create eproceedings and publishing on website instead of distributing proceedings after meetings", and "Using new model buses which have ecofriendly filters on their exhausts".

Considering data in Table 8, participants were generally careful with environmental practices and following guidelines of environmental codes of conducts. In addition, participant's intentions of contributing to the environmental good, using public transportation, and choosing closer meeting locations can also be evaluated as "positive," but participants were not sure about paying environmental tax on their travels.

Table 8. Intention Means of Participants Regarding Green Meetings Statements

\begin{tabular}{lrr}
\hline Variables & Mean & $\begin{array}{r}\text { Standard } \\
\text { Deviation }\end{array}$ \\
\hline $\begin{array}{l}\text { I am willing to take into account environmental practices (e.g., energy and water } \\
\text { conservation, recycling, local food, eco-label, etc.) }\end{array}$ & 4.52 & 0.81 \\
I am willing to follow guidelines of environmental codes of conducts required of the & 4.34 & 0.83 \\
meeting & & 1.03 \\
I am willing to use public transportation for my business travel to reduce greenhouse & 4.11 & 1.06 \\
l am willing to choose closer meeting locations when possible & 4.11 & 3.98 \\
$\begin{array}{l}\text { l am personally willing to take actions to contribute to environmental good (e.g. } \\
\text { biking to work, owning an electric car, recycling, saving energy, using renewable }\end{array}$ & 1.03 \\
energy sources at home, etc.) & 3.35 & 1.34 \\
\hline I am willing to pay an environmental tax on my business travel & &
\end{tabular}

Note: $\mathrm{N}=275$

Table 9. Comparing Green Meeting Intentions of Participants by Employment Sector

\begin{tabular}{lcccccc}
\hline Variables & \multicolumn{7}{c}{ Sector } \\
\cline { 2 - 7 } I want to attend green meetings & & Public & Private & Self-employment & Other & Total \\
& & 173 & 62 & 14 & 2 & 251 \\
& & $68.9 \%$ & $24.7 \%$ & $5.6 \%$ & $0.8 \%$ & $100 \%$ \\
& No & 18 & 3 & 1 & 2 & 24 \\
& & $75 \%$ & $12.5 \%$ & $4.2 \%$ & $8.3 \%$ & $100 \%$ \\
& Total & 191 & 65 & 15 & 4 & 275 \\
& & $69.5 \%$ & $23.6 \%$ & $5.5 \%$ & $1.5 \%$ & $100 \%$ \\
\hline I am ready to pay more for green & Yes & 106 & 35 & 8 & 1 & 150 \\
meetings & & $70.7 \%$ & $23.3 \%$ & $5.3 \%$ & $0.7 \%$ & $100 \%$ \\
& No & 85 & 30 & 7 & 3 & 125 \\
& \multirow{2}{*}{ Total } & $68 \%$ & $24 \%$ & $5.6 \%$ & $2.4 \%$ & $100 \%$ \\
& & $69.5 \%$ & 65 & 15 & 4 & 275 \\
& & & $23.6 \%$ & $5.5 \%$ & $1.5 \%$ & $100 \%$ \\
\hline
\end{tabular}

Table 10. Effects of Green Meeting Perception on Behavioral Intention Regarding Green Practices

\begin{tabular}{lccccc}
\hline Variables & $\begin{array}{c}\text { Standard Beta } \\
\text { Coefficient }\end{array}$ & $\mathbf{t}$ & $\mathbf{p}$ & Tolerance & VIF \\
\hline Constant & 0.344 & 0.924 & & & \\
Forming of social awareness & 0.253 & 2.736 & $0.007^{*}$ & 0.466 & 2.146 \\
Sustainable applications & 0.176 & 2.423 & $0.016^{*}$ & 0.560 & 1.787 \\
Eco-friendly material usage & 0.170 & 2.275 & $0.024^{*}$ & 0.461 & 2.170 \\
Conservation measures & 0.240 & 2.291 & $0.023^{*}$ & 0.538 & 1.859 \\
\hline Notes: ${ }^{*} p<0.05 ; \mathrm{F}=32.654(\mathrm{p}<0.000) ;$ Adjusted $\mathrm{R}^{2}=0.33$; Durbin-Watson=2.116 & & &
\end{tabular}


Considering results in Table 9, participants from the public sector want to attend green meetings more than participants serving in other sectors (68.9\%). Also, participants working in the public sector were ready to pay more for green meetings $(70.7 \%)$.

The term 'behavioural intention' is the core concept of the planned behaviour theory of Ajzen (1991). According to Ajzen, behavioural intentions bring a motivation to perform a certain behaviour and also measure how hard people are willing to try and perform a certain behaviour. He emphasizes that the stronger the intention to engage in the behaviour, the more likely it will be performed. Therefore, as a part of the research it is worth it to check if the meeting participants possess strong behavioural intentions towards eco-friendly practices regarding green meetings. In order to determine the effects of green meeting perception on behavioural intention regarding green practices, the authors used regression analysis. Four variables from factor analysis were used as independent variables, and the behavioural intentions of participants towards green meetings were used as dependent variables. In terms of the beta coefficients of the independent variables, the regression model (f: $32.654 ; p<0.05$ ) was significant and explained the changes $(33 \%)$ in the dependent variable (Adjusted $R^{2}$ : 0.33) (See Table 10).

Before considering the regression model, authors examined possible auto-correlation and multi-connection problems among independent variables. In this regard, VIF (variance increase factors) and tolerance values, together with Durbin-Watson test results, were taken into consideration. As can be seen in Table 7, there was no multi-connection problem, because VIF values of independent variables were below 10 and their tolerance values were over 0.10 . Also, there was no auto-correlation problem because Durbin-Watson values were between the 1.5 and 2.5 limits. Forming social awareness had the largest effect on behavioural intentions of participants regarding

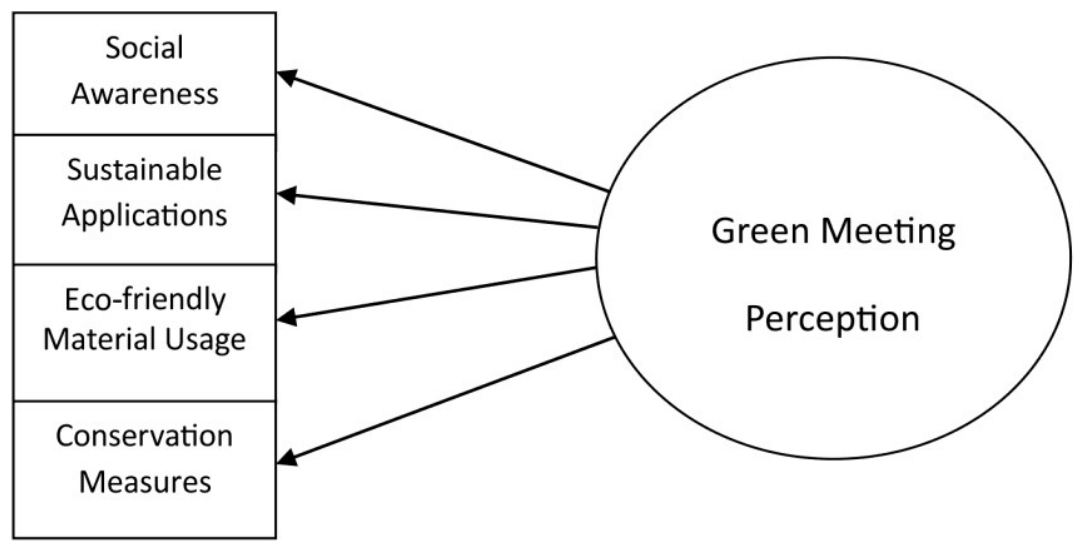

Figure 1. Proposed Measurement Model of Green Meeting Perception

Table 11. Green Meeting Perception Scale Fit Indexes and Reference Values

\begin{tabular}{lccl}
\hline Fit Index & $\begin{array}{c}\text { Green Meeting } \\
\text { Perception Scale }\end{array}$ & $\begin{array}{c}\text { Admissable } \\
\text { Values }\end{array}$ & \multicolumn{1}{c}{ Source } \\
\hline X2/df & 2.54 & $\leq 3$ & Kelloway, (1998) \\
RMSEA & 0.07 & $\leq 0.08$ & Hu and Bentler (1999) \\
RMR & 0.05 & $\leq 0.10$ & Cole (1987) \\
SRMR & 0.07 & $\geq 0.85$ & Schermelleh-Engel et al. (2003) \\
GFI & 0.87 & $\geq 0.80$ & Marsh, Balla and McDonald (1988) \\
AGFI & 0.83 & $\geq 0.90$ & Byrne (2001); Hair et al. (1998) \\
CFI & 0.96 & & \\
NNFI & 0.96 & & \\
\hline
\end{tabular}


green practices towards green meetings. Conservation measures and sustainable applications came as second and third, whereas eco-friendly material usage had the least effect.

There are various statistical methods for testing the model fitness. The most common used are Chi-Square Statistic, GFI (Goodness of Fit Index), CFI (Comparative Fit Index) and RMSEA (The Root Mean Square Error of Approximation). If Chi-Square statistic is $\mathrm{x} 2 / \mathrm{df}<2$, shows perfect fit and if it is $\mathrm{x}^{2} / \mathrm{df}<3$ shows admissible fitting (Kelloway, 1998). Goodness of Fit Index (GFI) and Comparative Fit Index (CFI); 0.85 or higher values are showing admissible fitting Anderson and Gerbing (1984: 156). The overall fit of CFA model was assessed performing chi-square test and a number of goodness of fit indices. The CFA results are shown in Table 11 and 12. Initially, fitting statistics are calculated for a 4 factored model. Chi-Square $\left(c^{2}=639.68\right.$, $p=0.000, d f=164)$ and the mentioned fit indices were evaluated. In the first stage it was seen that the CFA model was not satisfactory and it did not have the admissible values which are shown in Table 11 (RMR $=0.05, \mathrm{SRMR}=0.07$, $\mathrm{GFI}=0.81, \quad \mathrm{AGFI}=0.76, \quad \mathrm{RMSEA}=0.103$ ). In order to provide acceptable reference values, three modifications were performed. For modification the researchers had set the error covariance between items CM5-CM4 (decrease in $c^{2}=0.97$, EMU5-EMU4 (decrease in $c^{2}=0.57$ ) and SA4-SA3 (decrease in $\left.c^{2}=0.32\right)$. The results $\left(c^{2}=415.26, \quad N=275\right.$, $p=.000, \quad d f=163 ; \quad R M R=0.05, \quad S R M R=0.07$, GFI=0.87, AGFI=0.83, RMSEA=0.07) show that the fit of the measurement model was satisfactory enough. The mentioned values can bee seen in Table 11. Table 12 shows the factor loadings and $\mathrm{R}^{2}$.

The reliability of the scale was analysed by checking Cronbach's alpha and by calculating composite reliability estimates. According to

Table 12.Scale Items and Confirmatory Factor Analysis (CFA) Results

\begin{tabular}{|c|c|c|c|}
\hline Factor/Item & $\begin{array}{l}\text { Standard } \\
\text { Load }\end{array}$ & $\begin{array}{c}\text { t- } \\
\text { value }\end{array}$ & $\mathbf{R}^{2}$ \\
\hline \multicolumn{4}{|l|}{ Social Responsibility $(\mathrm{CR}=0.88)(\mathrm{AVE}=0.71)$} \\
\hline Increasing number of eco-friendly green meetings in the country and in the world & 0.84 & 16.51 & 0.70 \\
\hline \multirow{2}{*}{$\begin{array}{l}\text { Raising awareness of meeting participants regarding green meetings } \\
\text { Taking the support of government and other institutions in order to increase the } \\
\text { number of eco-friendly green meetings }\end{array}$} & 0.92 & 18.99 & 0.85 \\
\hline & 0.77 & 14.73 & 0.59 \\
\hline \multicolumn{4}{|l|}{ Sustainable Applications (CR=0.79) (AVE=0.35) } \\
\hline Holding evening reception outdoors to avoid using air conditioners & 0.70 & 12.20 & 0.49 \\
\hline Serving water in glass instead of plastic bottle & 0.61 & 10.36 & 0.37 \\
\hline Using paperless proceedings (USB drives) & 0.65 & 11.08 & 0.42 \\
\hline $\begin{array}{l}\text { Creating e-proceedings and publish on website instead of distributing } \\
\text { proceedings after meetings }\end{array}$ & 0.49 & 7.85 & 0.24 \\
\hline Holding small meetings in the garden & 0.67 & 11.74 & 0.45 \\
\hline r & & & \\
\hline Sending leftovers to surrounding farms after meetings & & & \\
\hline \multicolumn{4}{|l|}{ Eco-Friendly Material Usage $(C R=0.80)(A V E=0.35)$} \\
\hline \multirow{2}{*}{$\begin{array}{l}\text { Using potted plants/flowers as booth dividers instead of plastic } \\
\text { Using ecologically sustainable resources (e.g., banana leaves) as food } \\
\text { containers }\end{array}$} & 0.62 & 10.76 & 0.39 \\
\hline & 0.73 & 13.26 & 0.53 \\
\hline \multirow{2}{*}{$\begin{array}{l}\text { Using recycled backdrops, banners from previous meetings } \\
\text { During sightseeing, using new model buses which have eco-friendly filters on } \\
\text { their exhausts }\end{array}$} & 0.83 & 15.91 & 0.32 \\
\hline & 0.56 & 9.52 & 0.69 \\
\hline \multirow{2}{*}{$\begin{array}{l}\text { Using chairs and tables made of eco-friendly materials } \\
\text { Conservation Measures }(C R=0.76)(A V E=0.40)\end{array}$} & 0.63 & 11.00 & 0.40 \\
\hline & \multicolumn{3}{|c|}{ Conservation Measures $(\mathrm{CR}=0.76)(\mathrm{AVE}=0.40)$} \\
\hline Reducing waste consumption by eating all food (No leftovers) & 0.51 & 8.16 & 0.26 \\
\hline 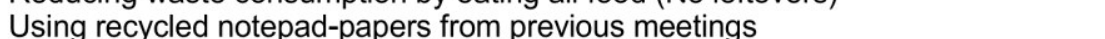 & 0.75 & 13.17 & 0.57 \\
\hline Turning air conditioners off in unoccupied meeting rooms & 0.70 & 11.97 & 0.56 \\
\hline \multirow{2}{*}{$\begin{array}{l}\text { Using motion-activated lavatory faucets that save water in meeting hotels } \\
\text { Using motion-activated lamp and lighting systems in available areas in meeting } \\
\text { hotels }\end{array}$} & 0.52 & 8.37 & 0.27 \\
\hline & 0.65 & 10.89 & 0.42 \\
\hline
\end{tabular}

Notes: ${ }^{*}$ Chi-Square $=405.89 ; \mathrm{df}=161 ; \mathrm{RMSEA}=0.075$ 
Nunnally and Bernstein (1994) Cronbach's alpha score is expected to be greater than 0.70 . Cronbach's alpha, ranging from 0.79 to 0.88 indicated and admissible internal consistency across the items in the constructs. The composite reliability estimates ranged from 0.79 to 0.88 . That shows the good internal consistency of the multiple indicators for each construct in the CFA model ( $>0.7$ : Hair, Anderson, Tatham and Black, 1998).

\section{Discussion}

The paper reported on the perceptions of medical meeting participants regarding green meetings. The findings indicate that the participants are mostly positive about the following issues, Conservation Measures (mean=4.65); Forming of Social Awareness (mean=4.61), Eco-friendly Material Usage (mean=4.22) and Sustainable Applications (mean=4.14). The high mean rates of the factors related to the perception of green meetings, show similarities with some of the findings obtained by Draper et al. (2011) and Park and Boo (2010). The research carried out by Draper et al. (2011), and Park and Boo (2010), concluded that the meeting planners' perceptions on recycling were found to have a higher mean. A research result achieving a high mean related to the Eco-friendly Material Usage (Energy Efficiency) clearly suggests that the study results match up with the findings of Draper et al. (2011). However, CMP's (Convention and Meeting Planners) were found to have moderate levels of perception. In consideration of this data it has emerged that meeting participants and CMP's have a positive perception about Usage of Eco-friendly material but they have perceptual differences about the Conservation Measures (Energy efficiency) and Sustainable Applications. The study concluded that the medical meeting participants are largely willing to attend green meetings but, nearly half of the participants are not willing to pay more for green meetings, contrary to the academic study carried out by Sox et al. (2013). Sox et al. (2013) found that attendees were willing to pay more to attend meetings at facilities providing staff trained in aspects of sustainability. Similarly the respondents are not willing to pay an environmental tax on their travels. This conclusion shows substantial similarity with findings obtained by Rittichainuwat and Mair (2012). In the study conducted by Mair and Jago (2010), key business event stakeholders stated that financial issues are (both cost and time involved) the main barrier to greening. Our research results indicate that the participants are indecisive about the cost of green meetings.

Although the study conducted by Rittichainuwat and Mair (2012), is intended to measure participants' perceptions of green meetings, it does not offer a clear factor structure related to attendee perceptions. This study offers an obvious, understandable and repeatable measurement model (Green Meeting Attendee Perception Scale) with statistically reliable and internationally acceptable high values. No other study was found to discuss what the factors of the perception of green meetings consist of. However, when the study conducted by Rittichainuwat and Mair (2012) was examined, it was observed that researchers did not give place to the statements containing the theme to create social awareness about eco-friendly green meetings. Within this study the expressions increasing number of eco-friendly green meetings in the country and in the world, raising awareness of congress participants regarding green meetings, taking the support of government and other institutions in order to increase eco-friendly green meetings were added to the scale after having the expert opinions.

\section{Conclusion and Suggestions}

This study investigates the effects of perceptions of medical meeting participants on behavioural intentions related to eco-friendly meetings. According to the results, participants supported all conservation measures to save food, water, electricity, and paper, and they attached great importance to eco-friendly, sustainable applications and looked positively on eco-friendly material usage. In addition, it can be concluded that medical meeting participants have higher positive perceptions regarding the formation of social awareness and increasing the number of eco-friendly green meetings in the world. Also, it can be stated that perceptions (related to green meetings) of respondents have an important effect on behavioural intentions regarding eco- 
friendly green meetings. In this context, respondents were positively inclined towards thinking of eco-friendly applications, giving importance to guidelines of environmental codes of conducts, using public transportation, and choosing closer meeting locations, whereas they were not sure about paying environmental tax on their travels. In addition, participants declared that green meetings improved their image of a meeting and its sponsors, as well as increasing brand value, which also has great importance for the future of meeting tourism. As a summary, the participants have a positive understanding of the green meeting concept, but they don't have enough desire to pay the costs of green meetings. One of the interesting results of this study is that most of the participants $(91.3 \%)$ have a desire to attend green meetings in the future, but nearly half of them (45.5\%) don't want to pay more for green meetings.

In the prior literature, as far as the authors are aware, there are few studies regarding green meetings, and, in these studies, findings of concrete factors are nearly impossible. In this context, this study can be seen as a starting point for defining the dimensions related to perceptions of respondents regarding green meetings. According to the results of factor analysis, four dimensions (forming of social awareness, sustainable applications, ecofriendly material usage, and conservation measures) relating perceptions of green meetings were defined and named as suitable. Moreover, this structure was confirmed by CFA. The factor structure of this study will be useful for future studies and might be the strongest point of this study. It is considered that the discovery of factor structure will help the further studies to develop better understanding. In addition, the authors tried to enrich prior scales by adding new statements related to the green meeting concept. As new survey statements, authors added the using of motion-activated water taps, lamps and lighting systems with motion sensors, using new model buses with eco-friendly filters on their exhausts, increasing the number of green meetings in the world, social awareness, and getting the support of governments. Finding out the social awareness dimension in EFA, provided better understanding of participant perceptions regarding green meetings and sustainable green practices for environmental measures. It is assumed that this new finding will contribute to literature and enhance improvement of the measurement model. The overall results are predicted to broaden the perspective regarding green meetings and green practices in the tourism industry. The authors believe that the findings will offer an insight into the future studies on greening. As a result of the study it is understood that green meeting perception consists of 4 factors (Forming Social Awareness, Sustainable Applications, EcoFriendly Material Usage, Conservation Measures).

As another advantage, there has been no other study showing the effects of green meeting perception on behavioural intention. This study shows a significant effect of participants' green meeting perceptions on their intention. In this context, it can be mentioned that meeting participants are taking care of food, water, electricity, and paper conservation, as well as using eco-friendly materials, sustainable applications, and forming social awareness. In order to have more effective and detailed results and to compare examples from other sectors, additional research must be done, especially on the green meeting concept. With detailed and updated information coming from participants in other conferences, comparing results will yield better perspective.

The authors also think that updating and increasing the scope of the questionnaire statements will enable better results. Future studies must focus on comparing the perceptions of different roles, such as participants, sponsors, organisers, and so on. As the green meeting is still an unpopular concept in Turkey, it would be a potential direction for future research to explore why meeting planners and practitioners in the field are not interested in embracing this concept.

\section{Practical Implications}

According to Nielsen Global Survey Company $55 \%$ of global online consumers are willing to pay more for products from companies they know are making a conscious effort to reduce their carbon footprint. That is up from $50 \%$ in 2012 and $45 \%$ in 2011. That is evidence of 
global consumers' willingness to pay for sustainable products but, as it is stated by Nielsen Company; in countries where scepticism toward corporate social responsibility runs high, marketers face an uphill struggle. In these markets, especially, social impact programmes must be incontestably authentic to a company's business objectives, vision and values (Frighetto and Wolf, 2013). Turkey can be counted as a country in which there is big rivalry between tourist companies due to the fact that tourism sector faces low season in the winter (short period for making profit) and sustainability may be pushed into the background as it may be regarded as timeconsuming. In this regard companies busy with touristic services should be motivated by sustainability and implementation of green applications. That motivation can be both governmental and stakeholder oriented. Additionally, consumers of tourist products or attendees of meetings should be informed about sustainability and its contribution to our planet. As shown in Table 9, most of the meeting attendees, related with public sector are willing to pay more for green applications. That is another important result that can be explained as increased awareness is due to the sustainable policies of official institutions and the awareness should be extended to the private sector. As shown in Table $5,80 \%$ of the participants have no information about green meetings and in order to resolve that some informative papers should be delivered through the convention bureau. Also some notes or emails about green meetings should be sent to potential participants together with developing some social media applications promoting green companies. As stated in Table 3 the participants have a positive viewpoint related to issues about the green meetings and its contribution to the value of brands and the sponsors of the event. It indicates that the green meetings would be more popular in future meeting organisations. There are limitations of this study as it cannot be generalised to all meeting attendees in Turkey. As a whole, the implications of this study show hopeful signs about willingness of attendees to support greening except covering the cost of it. In that respect, the businesses (PCOs, Travel operators, convention bureau officials and the other stakeholders) operating in the tourism industry should be more informed and motivated about the lower cost of sustainable applications compared to those commonly used. On the other hand, it should be strictly underlined that the meeting sector in Turkey is a lifesaver as tourism activities are seasonal, especially in sea-side regions and holiday destinations. The meetings have the potential to compensate the low season effects. All sectors of tourism including accommodation, transportation, food and beverage business and tour operators should put effort into sustainable applications as they are getting substantially more important globally.

\section{References}

Aase, S. (2009) A Guide to Greener Meetings. Journal of the American Dietetic Association, 109 (5), 800-804.

Ajzen, I. (1991) The Theory of Planned Behavior. Organizational Behavıor and Human Decision Processes, 50, 179-215.

Anderson, J. C., \& Gerbing D.W. (1984) The Effect of Sampling Error on Convergence, Improper Solutions, and Goodness-of-fit Indices for Maximum Likelihood Confirmatory Factor Analysis. Psychometrika, 49, 155-173.

ASTM International, (2014) Standards and Publications, URL: www.astm.org /Standards /E2772.htm. (Accessed on: 11.10.2014).

Bartlett, Kotrlik, J. W. K. J. W., \& Higgins, C. C. H. C. C. (2001). Organizational Research: Determining Appropriate Sample Size in Survey Research Appropriate Sample Size in Survey Research. Information Technology, Learning, and Performance Journal, 19(1), 43-50.

Bohdanowicz, P. (2005) European hoteliers' environmental attitudes: Greening the business. Cornell Hotel and Restaurant Administration Quarterly, 46(2), 188-204.

Boo, S. \& Park E. (2013) An Examination of Green Intention: The effect of Environmental Knowledge and Educational Experiences on Meeting Planners' Implementation of Green Meeting Practices, Journal of Sustainable Tourism 21 (8), 1129-1147.

Byrne, B. M. (2001) Structural equation modeling with AMOS, Mahwah $\mathrm{NJ}$ : Lawrence Erlbaum Associates. 
Chafe, Z., \& Honey, M. (2005) Consumer demand and operator support for socially and environmentally responsible tourism. URL: $\quad$ http://www.responsibletravel.org/ resources/documents/reports/Consumer_De mand_April_2005.pdf (Accessed on 05.03.2012)

Chen, T.Y. (2013) An Exploratory Study of Environmentally Sustainable Practices in the Events Industry, Cornell University Bachelors of Science dissertation.

Chen, Y.S. \& Chang, C.H. (2013) Towards Green Trust The Influences of Green Perceived Quality, Green Perceived Risk, and Green Satisfaction. Management Decision, 51 (1), 63-82.

Convention Industry Council, (2004) The Green Meetings Task Force Report. URL: http://www.conventionindustry.org/Files/CIC Green_Meetings_Report.pdf (Accessed on $\overline{10.07 .2015) . ~}$

Claver-Cortes, E., Molina-Azorin, J., PereiraMoliner, J., \& Lopez-Gamero, D. (2007) Environmental strategies and their impact on hotel performance. Journal of Sustainable Tourism, 15(6), 663-679.

Cole, D. A. (1987) Utility of Confirmatory Factor Analysis in Test Validation Research. Journal of Consulting and Clinical Psychology, 55, 1019-1031.

Convention Industry Council, (2004) Green Meetings' Report, URL: http://www.conventionindustr.org/files/CIC GreenMeetings Report:pdf (Accessed on 11.09.2014).

Cvent, (2012) Green meetings made easy. URL: http://www.cvent.com/en/resources /green-meetings-made-easy.shtml Accessed on 11.09.2014).

Draper, J., Dawson, M., \& Casey, E. (2011) An exploratory study of the importance of sustainable practices in the meeting and convention site selection process. Journal of Convention \& Event Tourism, 12 (3), 153178.

Environmental Affairs Division (2007) Environment Canada's Green Meeting Guide. URL: http://publications.gc.cal collections/collection 2009/ec/En4-572007E.pdf (Accessed on 10.07.2015).

EPA (2015) Chemicals Under The Toxic Substances Control Act (TSCA). URL: http://www.epa.gov/oppt/greenmeetings/pub s/basic.html (Accessed on 23.06.2015).

Expo2016Antalya (2015) Tourism Capital. URL: http://www.expo2016antalya.org.tr/en/ antalya/1/tourism-capital (Accessed on 03.02.2015).

Frighetto, J. \& Wolf, E. (2013) Nielsen: $50 \%$ of Global Consumers Surveyed Willing to Pay More For Goods, Services From Socially Responsible Companies, Up from 2011. URL: $\quad$ www.nielsen.com/tw/en/pressroom/2013/nielsen-50-percent-of-globalconsumers-surveyed-willing-to-pay-morefo.html (Accessed on 16.10.2015).

Gao, Y.L. and Mattila, A.S. (2014) Improving Consumer Satisfaction in Green Hotels: The Roles of Perceived Warmth, Perceived Competence, and CSR Motive. International Journal of Hospitality Management, 42, 2031

Hair, J., Anderson, R., Tatham, R., and Black, W. (1998) Multivariate Data Analysis. Upper Saddle River, N.J.: Prentice Hall.

Hu, L. T., \& Bentler, P. M. (1999) Cutoff criteria for fit indexes in covariance structure analysis: Conventional criteria versus new alternatives. Structural equation modeling: a multidisciplinary journal, 6(1), 1-55.

ICCA (1963-2012). Report A Modern History of International Association Meetings. URL: www.iccaworld.com /dcps/doc.cfm\%3 Fdocid \%3 D1626 +\&cd=2\&hl=tr\&ct $=c l n k \& g l=t r$ (Accessed on 10.07.2015).

ICCA (2013). Statistics Report, Country \& City Rankings, URL: http://www. destinationuppsala.se/Global/M\%C3\%B6ten /M\%C3\%B6ten\%20\%20PDF/ICCA_Country CityRankings2013.pdf (Accessed on 10.07.2015).

lowa Recycling Association (2014) lowa Green Meetings \& Events, URL:

http://lowarecycles.org/content.asp?ID=592 7. (Acessed on: 10.07.2015)

Kelloway, E. K., (1998) Using LISREL for Structural equation modeling. Thousand Oaks, CA: Sage Publishers.

Kim, S.E, Kim, H. and Chae, Y. (2014) A New Approach to Measuring Green Growth. Futures, 63, 37-48.

Kirk, D. (1998) Attitudes to environmental management held by a group of hotel managers in Edinburgh. International 
Journal of Hospitality Management, 17(1), 33-47.

Kovaleski,D.(2013) How Green Was My

Meeting?, URL: http://connection.ebscohost. com/c/articles/88910702/how-green-wasmy-meeting (Accessed on 11.09.2014).

Lee, J. S., Breiter, D. \& Choi, Y. (2011) Quality of a green destination as perceived by convention attendees: The relationship between greening and competitiveness, URL:

http://scholarworks.umass.edu/cgi/viewcont ent.cgi?article=1321\&context=gradconf_hos pitality (Accessed on 01.09.2014).

Lee, W. Barber T. And Tyrell, T.(2013) Green Attendees' Evaluation of Green Attributes at the Convention Centre: Using ImportancePerformance Analysis. Anatolia-An International Journal of Tourism and Hospitality Research 24 (2), 211-240.

Mair, J.and Jago L.(2010) The Development of a Conceptual Model of Greening in the Business Events Tourism Sector, Journal of Sustainable Tourism 18 (1), 77-94.

Marsh, H.W., Balla, J. R., \& McDonald, R. P. (1988) Goodness-of-fit Indexes in Confirmatory Factor Analysis: The Effect of Sample Size. Psychological Bulletin, 103, 91-410.

Millar, M. and Baloğlu, S.(2011) Hotel Guests' Preferences for Green Guest Room Attributes. Cornell Hospitality Quarterly, 52 (3), 302-311.

Mykletun, R.J., Bartkeviciute, M. and Puchkova, Y. (2014) Green Meetings-Do They Matter to Their Closest Stakeholders? Scandinavian Journal of Hospitality and Tourism 14 (3), 211-233.

Nunnally, J.C., and Bernstein, I.H. (1994) Psychometric theory (3rd ed.). New York: McGraw-Hill.

Park, E., \& Boo, S. (2010) An assessment of convention tourism's potential contribution to environmentally sustainable growth. Journal of Sustainable Tourism, 18(1), 95113.
Puchkova, Y.(2013) Multiple Stakeholders' Perceptions of Green meetings in Stavanger Region, Master Thesis, University of Stavanger Faculty of Social Sciences,

Rittichainuwat, B. and Mair, J. (2012) An Exploratory Study of Attendee Perceptions of Green Meetings. Journal of Convention \& Event Tourism, 13, 147-158.

Schermelleh, E., K., Moosbrugger, H. \& Müller, H. (2003) Evaluating the Fit of Structural Equation Models: Tests of Significance and Descriptive Goodness-of-Fit Measures. Methods of Psychological Research Online, 8(2), 23-74.

Spatrisano, A. (2014) What You Need to Know About Green Meetings Standards, URL: www.green0biz.com/blog/2014/01/21/epaapproved-standards-green-meetings (Accessed on 11.09.2014)

Sox, C., Benjamin, S., Carpenter, J \& Strick, S. (2013) An Exploratory Study of Meeting Planners and Conference Attendees' Perception of Sustainable Issues in Convention Centers. Journal of Convention \& Event Tourism, 14, 144-161.

Strick, S. and Fenich G.C.(2013) Green Certifications and Ecolabels in the MEEC Industry, Journal of Convention \& Event Tourism 14, 162-172.

Tzschentke, N., Kirk, D., \& Lynch, P. A. (2004) Reasons for going green in serviced accommodation establishments. International Journal of Contemporary Hospitality Management, 16(2), 116-124.

TÜRSAB, (2014) Congress Tourism. Türsab Magazine, 348, 8.

West Mediterranean Development Agency, (2012) Congress Tourism Sector Report. URL: http://www.baka.org.tr/uploads /1349952305BAKA-KONGRE-TURiZMiSEKTOR-RAPORU-11EYLUL.pdf. (Accessed on 04.03.2015) 